able works on ethics that have been published in recent years and it is a credit to American scholarship.

CoRNell University

Athletic Games in the Education of Women.

By Gertrude Dudley, Director of the Women's Department of Physical Education, University of Chicago, and Frances A. KELLOR, author of "Experimental Sociology," "Out of Work," etc. New York, Henry Holt \& Co. Price $\$ 1.25$ net.

Miss Dudley and Miss Kellor have presented a study which is unique, not only with reference to the influence of athletic sports and particularly team games upon women, but with reference to the nature and meaning of athletic sports themselves. The titles of the first three chapters are significant of this fact. They are: Citizenship and Social Education, Educational Value of Athletics, Instructors-their Responsibility and Training.

Tke plan of the book, after presenting these general sociological and pedagogical considerations, involves a discussion of athletics for girls as now carried on in secondary schools, colleges, universities and clubs. It involves also a discussion of the nature and effects of competition, and particularly of competition in public. The influence of games in promoting self-control, cooperation, fair play, loyalty, courage, responsibility, discipline, is discussed. The book takes up the matter of training in general and training specifically for basket ball, field hockey, etc.

The philosophical point of view taken is that the instinct feelings back of athletics are in the main those that make and control masculine character; that the ability to do team work is developed in the male by playing team games, such as baseball; and that modern woman, in her growing relationship to the community has need of these same elements of capacity for subordinating the self to the whole, of "playing the game," that a man gets through his athletics. The authors add: "These qualities are not essentially masculine. They are but human qualities, needed for human fellowship." There is frank recognition of the fact that the ethical element is secured only when the games are wisely conducted, and that too often only evil results are secured from badly managed athletics.

A question is raised in the mind of the reviewer as to the truth of the first assumption. Is woman really changing her relation to society? Is the present world-wide wave of unrest among women symptomatic of a permanent biological or sociological readjustment; and if such is the case, is the readjustment to come about through the social discipline of the female, by the same means through which the male has been disciplined? Are the social instinct feelings which have been so closely connected with woman's life - as far back as the ages of savagery-to be changed and developed into instinct feelings that tend toward the team spirit? The query is raised, but in the nature of the case it can not perhaps be answered, for it is easier to look back than to look forward.

New YoRK,

\section{Luther Halsey Gulick}

June 15, 1909

FISHES OF THE RUSSIAN EMPIRE AND OF AFRICA

A MUCH-NEEDED "Preliminary Synopsis of the Fishes of the Russian Empire" from a systematic and geographical point of view has been published by V. I. Gratzianow. It is dated on the title page, Moscow, 1907, but the copy in the Smithsonian Library was received April 3, 1909. The work is entirely in Russian and consequently will be of little use to most ichthyologists except for what may be gathered from the scientific names. The classification of Jordan is adopted mainly. 948 species are enumerated under 331 genera and 101 families. Dichotomous tables are given for the various groups.

The first volume of a "Catalogue of the Fresh-water Fishes of Africa in the British Museum (Natural History)," by George Albert Boulenger, has been published by the museum. It embraces the Selachians and the Teleostomes down to and including the Cyprinoid genera Labeo, Discognathus and Varicorhinus. Descriptions of all the species 
and figures of almost all (270) are given. It is expected that the work will be completed in three volumes. An extended notice may be expected on the completion.

\section{Theo. GirL}

\section{SCIENTIFIC JOURNALS AND ARTICLES}

The Journal of Experimental Zoology, Vol. VI., No. 3 (June, 1909) contains the following articles: "Studies on the Physiology of Reproduction in the Domestic FowlI., Regulation in the Morphogenetic Activity of the Oviduct," by Raymond Pearl. This paper describes a case in which a regulatory change in the shape of eggs successively laid by the same hen occurred, the change in shape following a logarithmic law. "The Physiology of Nematocysts," by O. C. Glaser and C. M. Sparrow. Experiments made on living nematocyst-bearing tissues as well as on artificially isolated nettling organs show that a rise in internal pressure brings about the discharge of the stinging thread; that osmotic pressure is responsible for the explosions of nematocysts in Eolids; that this may explain the similar processes among Colenterates; and finally that the nettling threads, contrary opinions notwithstanding, are capable of penetrating the tissues of other animals. "Observations on the Life History of Tillina magna," by L. H. Gregory. A study of the morphology, physiology and methods of reproduction of the organisms, and its reactions to stimulations during different periods in the life history, with especial reference to the questions of artificial rejuvenescence and the inter-relations of nucleus and cytoplasm. "Studies of Tissue Growth-II., Functional Activity, Form Regulation, Level of the Cut and Degree of Injury as Factors in Determining the Rate of Regeneration-The Reaction of Regenerating Tissue on the Old Body," by Charles R. Stockard. The rate of regeneration in the medusa, Cassiopea, is independent of functional activity; form regulation inhibits growth; and the level of the cut determines the rate of regeneration in many species. The degree of injury does not exert the same influence over the rate of regeneration in all species; the new tissue has an excessive ca- pacity for the absorption of nutriment even to the detriment of the old body.

\section{SPECIAL ARTICLES}

ON THE RESTORATION OF SKELETONS OF FOSSIL

\section{VERTEBRATES}

IN a paper published last October ${ }^{1}$ the writer, in referring to the mounted carnivorous dinosaur in the American Museum of Natural History supposed to be Allosaurus or Creosaurus, compared its hands with those of Marsh's restoration of Allosaurus. Inasmuch as the hands of the New York specimen are wholly artificial and those of Marsh's figure mostly or wholly so, it will be seen that the comparison was of something less than no value at all. A serious error on the part of the writer must therefore be confessed. How it came to be committed will probably be of interest to nobody.

Although the quite complete hind leg of Allosaurus on which Marsh based his restoration $^{2}$ is in the U. S. National Museum, the materials belonging to the fore leg, restored by Marsh on the plate cited, are not in that museum and I therefore do not know just what parts were in Marsh's possession. From his language we have the right to suppose that he had at least the scapula, the coracoid, the humerus and some claws. ${ }^{3}$ These parts, then, ought to be available in making comparisons with corresponding parts of related dinosaurs. Further differences between Allosaurus and Creosaurus are said by Marsh to be found in the elongated sacral vertebræ of the latter genus and the transverse processes, which are placed higher up on the centra than in Allosaurus.

It appears to the writer that some animadversions may justly be made on the methods of preparing restorations of fossil animals, both as shown in the scientific journals and as displayed in our museums. It seems incontestable that the public has a right to know on what materials all reconstructions, as well as

${ }^{1}$ Proc. U. S. Nat. Museum, XXXV., pp. 351-66.

2 "Dinosaurs of North America," Pl. XII., fig. 2.

${ }^{3}$ Amer. Jour. Sci., XXVII., 1884, p. 334, Pl. XII., fig. 1.

${ }^{4}$ Amer. Jour. Sci., XVII., 1879, p. 91. 